\title{
Real-Time Polymerase Chain Reaction Quantification of Phytophthora capsici in Different Pepper Genotypes
}

\author{
C. Silvar, J. Díaz, and F. Merino
}

Departamento de Bioloxía Animal, Bioloxía Vexetal e Ecoloxía, Universidade da Coruña, A Coruña, Spain. Accepted for publication 8 August 2005.

\begin{abstract}
Silvar, C., Díaz, J., and Merino, F. 2005. Real-time polymerase chain reaction quantification of Phytophthora capsici in different pepper genotypes. Phytopathology 95:1423-1429.

Reliable and sensitive quantification of Phytophthora capsici in pepper plants is of crucial importance in managing the multiple syndromes caused by this pathogen. A real-time polymerase chain reaction (PCR) assay was developed for the determination of $P$. capsici in pepper tissues. DNA levels of a highly virulent and a less virulent isolate were measured in different

postinoculation. Thereafter, the increase was rapid in susceptible cultivars and slower in resistant ones. The amount of pathogen DNA quantified in each pepper genotype correlated with susceptibility to Phytophthora root rot. Likewise, there was a relationship between the virulence of the pathogen and the degree of colonization. Differences also were found in oomycete amount among pepper tissues, with maximal pathogen biomass occurring in stems. The real-time PCR technique developed in this study was sensitive and robust enough to assess both pathogen development and resistance to Phytophthora root rot in different pepper genotypes.
\end{abstract} pepper genotypes with varying degrees of resistance. Using SYBR Green and specific primers for P. capsici, the minimal amount of pathogen DNA quantified was $10 \mathrm{pg}$. Pathogen DNA was recorded as early as $8 \mathrm{~h}$
Additional keywords: Capsicum annuum, PI201234, Serrano Criollo de Morelos 331, Yolo Wonder.
In a plant-pathogen interaction where the result is disease, the detection and quantification of pathogen biomass in the plants is crucial. Traditionally, the common methods used to evaluate disease severity consisted of scoring visual symptoms displayed by the plant. For pathogens able to kill plants completely, survival rates are scored to evaluate disease resistance. Alternatively, for pathogens causing necrosis without killing the host, the degree of necrosis over time is used as a measure to monitor resistance (9). However, these techniques have several limitations. First, they can be used only when the pathogen-host interaction results in visible disease symptoms, which is a limiting factor in the earliest stages of infection. Second, there is not always a straightforward relationship between disease symptoms and pathogen development in plants $(24,53)$. Indeed, a tolerant host can show no disease symptoms, without reduction in pathogen growth within the plant $(12,42)$. Therefore, a method for direct assessment of pathogen development in infected plants was necessary.

Several techniques have been developed with the aim of quantifying pathogen biomass. Some of these are based on the measurement of compounds such as ergosterol or chitin $(18,21,32,40,43)$ which are present in the pathogen but not in the host. The problem with these methods is the lack of specificity and the fact that they can be used only to assess colonization by pathogens that possess these constituents (3). Another group of techniques includes the use of immunological methods for pathogen biomass determination $(13,22,29,38)$. However, among the drawbacks of these methods are the difficulty in obtaining antibodies with the required specificity for particular fungi (56), false-positive reactions $(51,52)$, and interference of plant factors with the measured parameter $(35,53)$.

In recent years, the polymerase chain reaction (PCR) method has been used successfully to detect and identify fungal pathogens

Corresponding author: F. Merino; E-mail address: fuenme@udc.es

DOI: 10.1094/PHYTO-95-1423

(C) 2005 The American Phytopathological Society
(48). Among the PCR-based methods, real-time PCR has proven to be a simple yet reliable technique to quantify viral, bacterial, fungal, and oomycete plant pathogens, and increasingly is being used in plant pathology $(5,33,37,47,55)$. In this technique, the DNA of a specific target organism can be quantified by measurement of the intensity of fluorescence with time during the exponential phase of DNA amplification. Quantification of DNA in unknown samples will be possible by direct comparison with standards amplified in parallel reactions (36). The main advantage of this technique compared with the conventional one, end-point quantitative PCR, is that the amplification products can be monitored as they are accumulated in the log-linear phase of amplification. Therefore, it is more accurate, less time-consuming, and better suited, especially when the objective is to discriminate between slightly different levels of infection (58).

Phytophthora root rot, caused by Phytophthora capsici Leonian, is the most destructive disease of pepper crops in Spain $(39,44)$. In susceptible plants, the pathogen penetrates through the collar, causing necrosis in that area. At the same time, the plant becomes withered while the pathogen advances systemically toward both the stem and the root, causing an obstruction in the vascular system. The infected tissues become dry, sunken, and parchmentlike, and turn dark in color. Finally, the plant dies at the last stage of infection. Although the most effective method to combat the pathogen is based on the use of fungicides, some cultivars with different levels of resistance to $P$. capsici have been reported. Indeed, several different screening methods have been developed to distinguish Phytophthora-resistant individuals from susceptible ones $(1,7,8,19)$. Different sources of resistance to $P$. capsici have been reported in Capsicum annuum L.; among the genotypes that exhibit resistance to Phytophthora root rot are United States Department of Agriculture (USDA) PI201234 and USDA PI201232, as well as Serrano Criollo de Morelos 331 (SCM331) and SCM334, the latter being more resistant to $P$. capsici than the former $(4,20,41)$.

In a previous study (50), we developed a PCR procedure for the early detection of $P$. capsici in pepper plants. Specific primers for 
P. capsici, based on the internal transcribed spacer (ITS) region of ribosomal DNA, were designed and tested for their sensitivity and specificity as well as for their ability to detect the pathogen in artificially and naturally infected pepper plants (50). The development of a real-time approach enabled the quantification of pathogen biomass in plants over the course of infection. This method will facilitate the characterization of host-pathogen interactions. The aims of the present work were to (i) develop a real-time PCR assay to quantify $P$. capsici biomass in pepper plants and (ii) monitor pathogen growth in pepper plants in relation to different levels of pathogen virulence and host susceptibility.

\section{MATERIALS AND METHODS}

Pathogen material. In recent works carried out in our laboratory (C. Silvar, F. Merino, and J. Díaz, unpublished data), a population of Spanish $P$. capsici isolates was characterized according to their virulence. Two different isolates, one highly virulent (UDC196Pc) and one less virulent (UDC248Pc), were selected for this work. The isolates were maintained on potato dextrose agar (PDA) for further use. To obtain mycelium, the isolates were grown in still culture in pea broth (11). After 1 week of incubation at $24^{\circ} \mathrm{C}$, mycelium was collected and lyophilized for extended storage.

Plant material. Three different cultivars of pepper plants were used: susceptible cv. Yolo Wonder, and SCM331 and PI201234, each with different levels of resistance to $P$. capsici, SCM331 being the most resistant (4). Moreover, a susceptible local cultivar (Padrón) was included because of its economic value in northwestern Spain. Plants were transferred into pots and grown separately in a chamber at $25^{\circ} \mathrm{C}$ and a photoperiod of $16 \mathrm{~h}$ of light and $8 \mathrm{~h}$ of darkness until they were 3 weeks old.

Pathogen inoculation, quantification bioassay, and disease assessment. A suspension of zoospores from UDC196Pc and UDC248Pc were obtained according to Larkin et al. (30). Pepper plants were inoculated with a concentration of $10^{4}$ zoospores $\mathrm{ml}^{-1}$ by adding $5 \mathrm{ml}$ of the inoculum into the soil. For the quantification of pathogen DNA, samples of leaves, stems, and roots were collected at $8,24,48$, and $72 \mathrm{~h}$ postinoculation in the different cultivars. Three independent experiments were carried out.

In parallel, assays were carried out with the aim of studying the disease progression in different cultivars during a time period. With this purpose, 10 plants of each cultivar were inoculated with the two different isolates (UDC196Pc and UDC248Pc). Disease severity was rated for 20 days after inoculation on a scale of 0 to 5 , where $0=$ no visible symptoms; $1=\leq 50 \%$ of stem with watersoaked lesions, $\leq 50 \%$ of leaves wilted, or both; $2=>50 \%$ of stem with water-soaked lesions or $>50 \%$ of leaves wilted; $3=$ both $\leq 50 \%$ of stem with water-soaked lesions and $>50 \%$ of leaves wilted or both $>50 \%$ of stem with water-soaked lesions and $\leq 50 \%$ of leaves wilted; $4=>50 \%$ of stem with water-soaked lesions and $>50 \%$ of leaves wilted; and $5=$ dead plant. Percentage of diseased plants (incidence) also was recorded during the time course of infection. In this case, two independent experiments were performed.

Isolation of $\boldsymbol{P}$. capsici from artificially infected plants. Colonization of pepper plants by $P$. capsici was determined in each of the pepper cultivars studied by isolating the pathogen on PDA. During the host-plant infection assay, samples of plants were collected at 8, 24, 48, and $72 \mathrm{~h}$ postinoculation. Entire plants were surface disinfected with $\mathrm{NaClO}(10 \%)$ for $5 \mathrm{~min}$, washed with distilled water, dried, and plated onto PDA medium. Plates were incubated at $24^{\circ} \mathrm{C}$ in the dark for 7 days.

DNA extraction. For DNA extraction, both pathogen and plant material (0.2 $\mathrm{g}$ fresh weight [FW]) were ground with liquid nitrogen to a fine powder using a mortar and pestle. All the powder was transferred to an Eppendorf tube containing extraction buffer (0.1 M Tris-HCl, $\mathrm{pH} 7,1.4 \mathrm{M} \mathrm{NaCl}, 0.2 \% \beta$-mercaptoethanol, $1 \%$ polyvinyl pyrrolidone, and $2 \%$ cetyltrimethylammonium bro- mide). Subsequently, extraction with phenol/chloroform/isoamyl alcohol (25:24:1, vol/vol) was carried out. DNA was precipitated with isopropanol, washed with cold ethanol (70\%), and resuspended in sterile distilled water.

Real-time PCR assay. Real-time PCR assays for quantification of both isolates in different cultivars were conducted using primer pair CAPFW/CAPRV1 (50), which defines an amplicon of $452 \mathrm{bp}$ specific for $P$. capsici. Real-time PCR was performed in an iCycler (BioRad, Hercules, CA) apparatus and results were analyzed with the manufacturer's software (Optical System Software, v. 3.0; BioRad). Each reaction mixture $(20 \mu \mathrm{l})$ contained $2.5 \mu \mathrm{l}$ of undiluted DNA extract, $1 \times$ iQ SYBR Green Supermix (BioRad), and $0.3 \mu \mathrm{M}$ of each primer. In negative controls, the DNA extracts were obtained from noninoculated plants of the same age and same culture conditions as inoculated ones. Additional negative control reactions contained the same mixtures with $2.5 \mu \mathrm{l}$ of sterile water replacing the DNA. The thermal cycling conditions consisted of an initial denaturation at $95^{\circ} \mathrm{C}$ for $2 \mathrm{~min}$ followed by 40 cycles at $95^{\circ} \mathrm{C}$ for $30 \mathrm{~s}, 56^{\circ} \mathrm{C}$ for $30 \mathrm{~s}, 72^{\circ} \mathrm{C}$ for $1 \mathrm{~min}$, and $84^{\circ} \mathrm{C}$ for $15 \mathrm{~s}$. A final extension step at $72^{\circ} \mathrm{C}$ for $5 \mathrm{~min}$ was added. Fluorescence of the target amplicon (melting temperature $(\mathrm{Tm})=$ $86.5^{\circ} \mathrm{C}$ ) was detected at $84^{\circ} \mathrm{C}$. After the final amplification cycle, a melting curve temperature profile was obtained by heating to $95^{\circ} \mathrm{C}$, cooling to $65^{\circ} \mathrm{C}$, and slowly heating to $95^{\circ} \mathrm{C}$ at $0.5^{\circ} \mathrm{C}$ every $10 \mathrm{~s}$ with continuous measurement of fluorescence at $520 \mathrm{~nm}$. A standard curve was constructed by plotting the logarithm of 10 -fold serial dilutions from 100 to $10^{-3} \mathrm{ng}$ of $P$. capsici DNA against the cycle threshold $(\mathrm{Ct})$ values. The $\mathrm{Ct}$ value is the cycle number at which the fluorescence emission of the PCR amplicon could be distinguished from the background.

In another assay, a 10-fold serial dilution of genomic DNA starting from $100 \mathrm{ng}$ was added to samples containing $100 \mathrm{ng}$ of pepper genomic DNA. This was done in order to test whether the presence of samples of plant DNA would interfere with the accurate quantification. When constructing a regression line with these data, a linear relationship was observed, as happened in the standard curve (data not shown). From these results, it was concluded that addition of host DNA has no effect on pathogen DNA quantification.

The amount of pathogen DNA in unknown samples was calculated by monitoring the $\mathrm{Ct}$ value at which the fluorescence emission could be differentiated from the background and comparing this $\mathrm{Ct}$ value with the point values of the linear regression line of the standard curve. Furthermore, to confirm that only one PCR product was amplified in the inoculated plants and no amplification product was obtained in the negative controls, all reactions were analyzed by electrophoresis in a $1 \%$ (wt/vol) agarose gel in $1 \times$ Tris-borate-EDTA buffer (31) and stained with ethidium bromide $\left(5 \mu \mathrm{g} \mathrm{ml}^{-1}\right)$ for visualization.

Statistical analyses. Statistical analyses were performed using Statgraphics Plus for Windows, 5.1 Professional Version (StatPoint, Inc., Herndon, VA). Data of pathogen DNA quantification among cultivars were analyzed using the Kruskal-Wallis test $(P \leq 0.05)$ followed by the multiple comparison procedure of Conover (10).

\section{RESULTS}

Disease assessment in different pepper cultivars. The capacity of the two $P$. capsici isolates to infect pepper plants was tested in a group of four pepper genotypes, differing in their degree of susceptibility to the pathogen. Data on disease severity were plotted over time to obtain disease progress curves (Fig. 1). In general, differences could be observed among cultivars, isolates, and cultivar-isolate interactions. Susceptible cv. Yolo Wonder showed high disease severity with both $P$. capsici isolates. Seedlings were attacked primarily in the collar region and the infection rapidly expanded up the hypocotyl, reaching the cotyledons within a few days. Host plants revealed the first visible symptoms 
on the fourth day after inoculation, although the disease progress over time was higher in plants inoculated with UDC196Pc than in those infected with UDC248Pc. In the first case, a maximal infection (severity index $=4.8$ ) was reached at 17 days after infection (Fig. 1A) and the percentage of infected plants at the end of the bioassay was $95 \%$ (data not shown). In the Yolo WonderUDC248Pc interaction, however, disease progression was slower and the severity rating achieved at the end of the ongoing period was only 1.5 (Fig. 1B), with only $30 \%$ diseased plants (data not shown). After inoculation with UDC196Pc, the infection pattern displayed by local cv. Padrón was similar to that in Yolo Wonder, but showed the highest degree of susceptibility (severity rate $=5$ and percentage of infected plants $=100 \%$ ) (Fig. 1A). However, after inoculation with UDC248Pc, the severity achieved by Yolo Wonder was higher than in Padrón (Fig. 1B).

In contrast, resistant genotypes showed the lowest disease severity. No disease symptoms were observed when the plants were infected with UDC248Pc, and slower progress curves were obtained in the PI201234- or SCM331-UDC196Pc system compared with those in susceptible cultivars. In the last case, more symptoms developed in PI201234 than in SCM331, with 40 and $20 \%$ disease percentage (data not shown) and 2 and 1 severity index, respectively, at the end of the trials. Noninoculated plants did not show any symptoms (data not shown).

$P$. capsici was isolated successfully from leaves, stems, and roots in all pepper genotypes inoculated with both isolates at 24, 48, and $72 \mathrm{~h}$ after inoculation. However, no pathogen isolation was possible at $8 \mathrm{~h}$ in any pepper- $P$. capsici system (data not shown).

Real-time PCR adjustment and DNA standard curves. Preliminary runs of real-time PCR without the step at $84^{\circ} \mathrm{C}$ for $15 \mathrm{~s}$ were carried out with the aim of detecting some possible non-

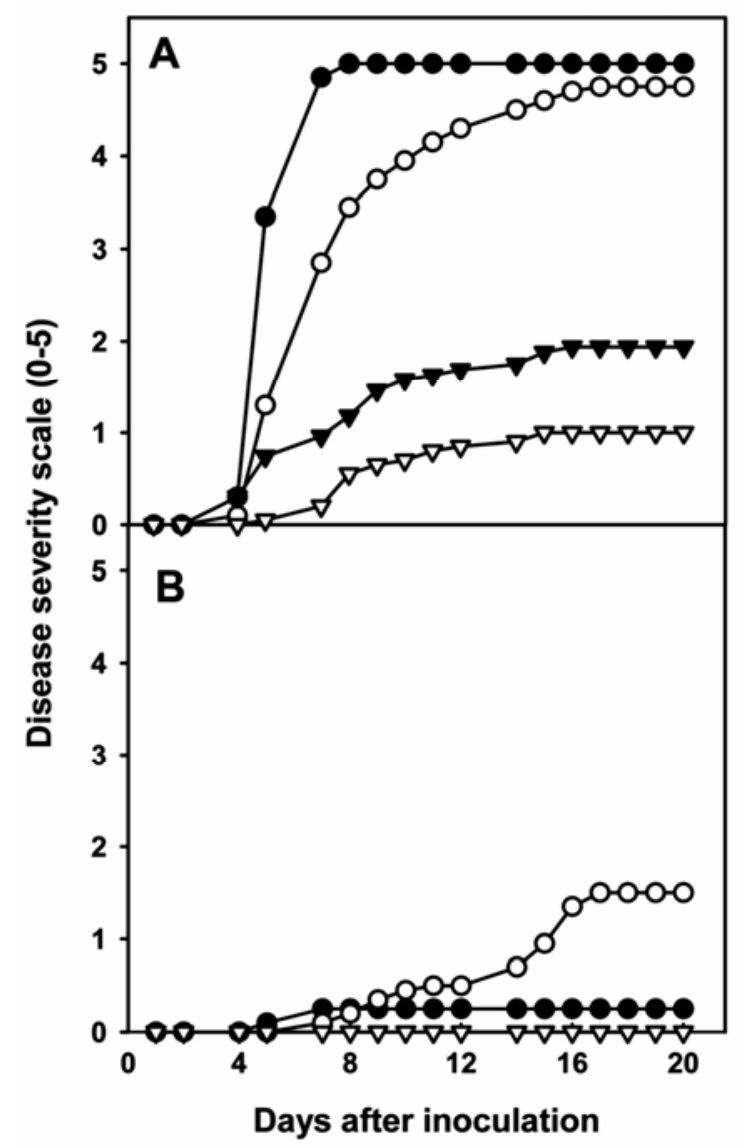

Fig. 1. Disease progress curves of pepper cultivars inoculated with A, UDC196Pc or B, UDC248Pc. Each plotted point is the mean value of 20 plants from two independent experiments. Padrón $(\bullet)$, Yolo Wonder $(O)$, PI201234 ( $)$, and SCM331 ( $\nabla)$. specific amplification products or primer-dimers. Melting curve profiles from those runs revealed the presence of such products, with a $\mathrm{Tm} \leq 82^{\circ} \mathrm{C}$. Therefore, to avoid any possible disturbance in the quantification of the target amplicon $\left(\mathrm{Tm}=86.5^{\circ} \mathrm{C}\right)$, an additional step $\left(84^{\circ} \mathrm{C}\right.$ for $\left.15 \mathrm{~s}\right)$ was included in the real-time PCR amplification program and the reading of the fluorescence emission was set at this point. Additionally, to confirm the presence of the single expected amplicon of $452 \mathrm{bp}$, final products of realtime PCR from both standard curve and unknown samples were visualized in agarose gels (data not shown).

A standard curve was constructed by plotting known concentrations of $P$. capsici DNA against the $\mathrm{Ct}$ values obtained from real-time PCR (Fig. 2). In order to validate the reproducibility of the real-time PCR method, PCR amplifications were conducted with duplicate samples of pathogen DNA obtained from four different preparations. Highly reproducible $\mathrm{Ct}$ values with very small standard deviations were observed, the linear regression coefficient of the standard curve being $r=0.968$. Within this standard curve, each 10-fold difference in initial DNA amounts was represented by approximately four-cycle differences in $\mathrm{Ct}$. Under the PCR conditions tested, the minimum starting quantity of pathogen DNA that could be accurately quantified in our assays was $10^{-2} \mathrm{ng}$, which corresponded to a $\mathrm{Ct}$ value of $36.97 \pm 1.06$. A Ct of $37\left(6 \times 10^{-3} \mathrm{ng}\right.$ of DNA according to the standard curve $)$ was considered to be the threshold value suitable for quantification, because PCR efficiency at a higher number of cycles was far from the value 1 (100\% efficiency).

Quantification of $\boldsymbol{P}$. capsici DNA in pepper plants. Pathogen DNA was quantified in plants using real-time PCR with SYBR Green before first symptoms of the disease were observed in plants (Figs. 3, 4, and 5). Indeed, symptoms did not appear in infected plants until 4 days after inoculation; however, with the real-time PCR assay, pathogen DNA could be quantified as early as $8 \mathrm{~h}$ postinoculation in all the organs of the plant. From that time point, the pathogen DNA in pepper organs increased progressively until the end of the bioassay. Real-time PCR quantification showed important differences among the different organs. In general, stems were more heavily colonized than roots, and the latter more than leaves. In all cases, the maximal amount of pathogen DNA occurred at $72 \mathrm{~h}$ after inoculation. Although the pathogen was able to colonize all the susceptible and resistant pepper cultivars evaluated, the extent of colonization varied highly among cultivars with different levels of resistance. In most of the cases, higher amounts of pathogen DNA were present at 72 $\mathrm{h}$ after inoculation in susceptible cultivars (Padrón and Yolo Wonder) than in the more resistant ones (PI201234 and SCM331). In the susceptible cultivars, pathogen DNA was detected earlier

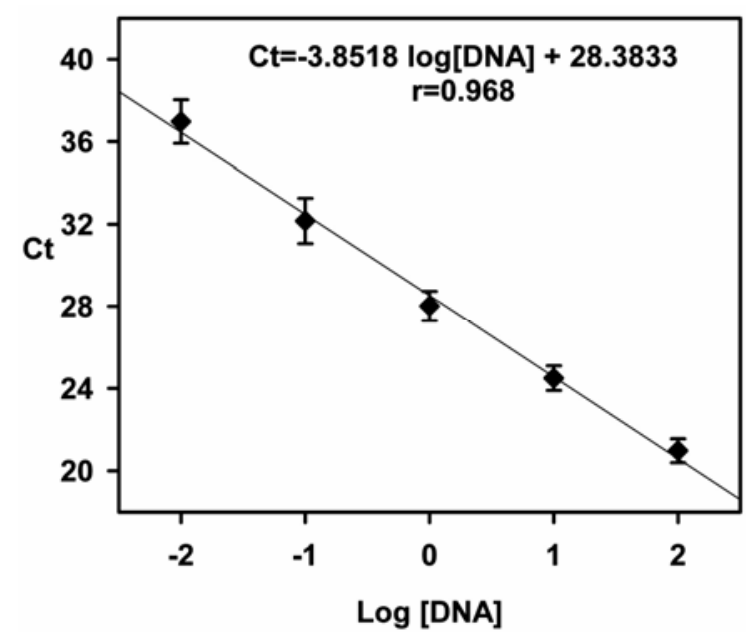

Fig. 2. Standard curve for real-time polymerase chain reaction analysis of a 10-fold serial dilution of Phytophthora capsici DNA. 
and increased sharply over time whereas, in the resistant plants, the variations in pathogen development were slighter. Significant $(P \leq 0.05)$ differences were found among resistant and susceptible cultivars as early as $24 \mathrm{~h}$ postinoculation in the stem for the UDC196Pc isolate (Fig. 4A) although, at $48 \mathrm{~h}$, there was no significant differences. The differences were significant at $72 \mathrm{~h}$ postinoculation in all the organs and isolates, except for the combination of the roots and the isolate UDC196Pc (Fig. 5A). Comparing the cultivars separately, susceptible cvs. Padrón and Yolo Wonder displayed a similar pattern of pathogen invasion, but significant differences between them were found in the roots at 48 and $72 \mathrm{~h}$ postinoculation (Fig. 5A and B). For the resistant cultivars, significant differences were found in SCM331 compared with the partially resistant cv. PI201234 only in the case of roots at $48 \mathrm{~h}$ postinoculation (Fig. $5 \mathrm{~A}$ and $\mathrm{B}$ ). In any case, the accumulation of pathogen DNA in these resistant genotypes was slower than that in susceptible cultivars and the amount of pathogen DNA generally remained lower during the study.

With regard to the two $P$. capsici isolates, a different pattern of infection was observed. Up to $5.9 \mathrm{ng} \mathrm{g}^{-1} \mathrm{FW}$ of pathogen DNA was observed as soon as $8 \mathrm{~h}$ postinoculation in the Padrón- or Yolo Wonder-UDC196Pc interactions (Fig. 4A) whereas, in susceptible cultivar-UDC248Pc interactions, the maximal amount of DNA detectable was $0.2 \mathrm{ng} \mathrm{g}^{-1} \mathrm{FW}$ (Fig. 4B). In the same way, the average pathogen DNA in the resistant cultivar-UDC196Pc system was $1.4 \mathrm{ng} \mathrm{g}^{-1} \mathrm{FW}$, whereas it could not be detected in PI201234 or in SCM331 until $24 \mathrm{~h}$ after infection, when the plants were inoculated with the least virulent pathogen (UDC248Pc). During the remaining period, the amount of UDC196Pc (the isolate previously characterized as more virulent) DNA was up to 10

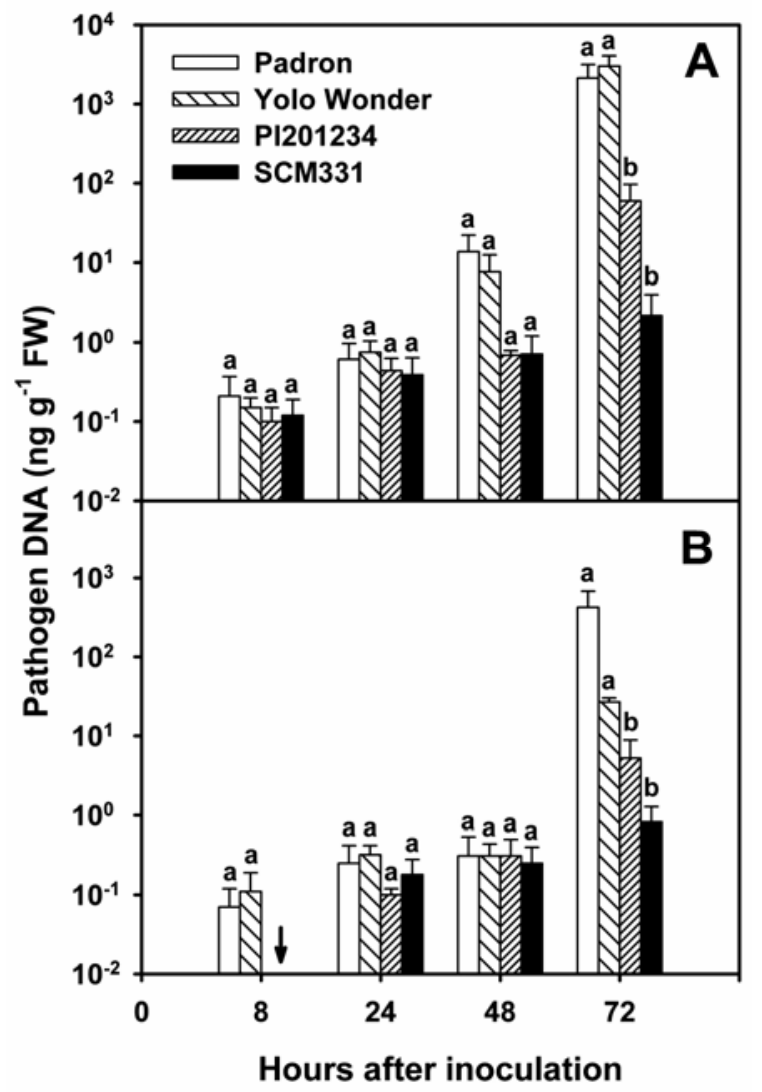

Fig. 3. Phytophthora capsici DNA quantification in leaves of different pepper cultivars inoculated with A, UDC196Pc or B, UDC248Pc. Vertical arrow ( $\downarrow$ ) indicates DNA samples (PI201234 and SCM 331) that could not be quantified. Data are the mean and standard error of three independent experiments. Within the same time postinoculation, different letters indicate significant differences between cultivars in a Kruskal-Wallis test $(P \leq 0.05)$ followed by the multiple comparison procedure of Conover (10). times higher than UDC248Pc (less virulent) in all cultivars evaluated. These results correspond with those obtained in the severity assessment assay, where clear differences between isolates also were observed.

\section{DISCUSSION}

One of the objectives of this study was the development of an accurate quantification method of pathogen colonization in host tissue using real-time PCR technology and the use of this method for a better understanding of the interaction between different pepper genotypes and $P$. capsici isolates. With this purpose, four pepper cultivars were artificially infected with two $P$. capsici isolates, differing in their degree of virulence toward pepper plants. Pathogen DNA was monitored and quantified in a time course after inoculation using a quantitative SYBR Green PCR assay. In recent years, real-time PCR assays have been widely used for the detection and quantification of fungal plant pathogens $(2,15,48)$. Similar studies have been carried out in Phytophthora spp. (5,6, $23,26,55)$. However, to the best of our knowledge, no attempts had been made to apply the real-time PCR technology for quantification of $P$. capsici in pepper plants.

In our study, the results showed that real-time PCR can be successfully implemented for the quantification of pepper colonization by $P$. capsici. The technique was highly reproducible, the correlation coefficient of the standard curve constructed with different replications being 0.968 . At the same time, the method was quite sensitive, being able to readily detect, using the unspecific SYBR Green dye and specific primers to $P$. capsici, up to $10^{-2} \mathrm{ng}$ of pathogen DNA. Similar quantification limits have been

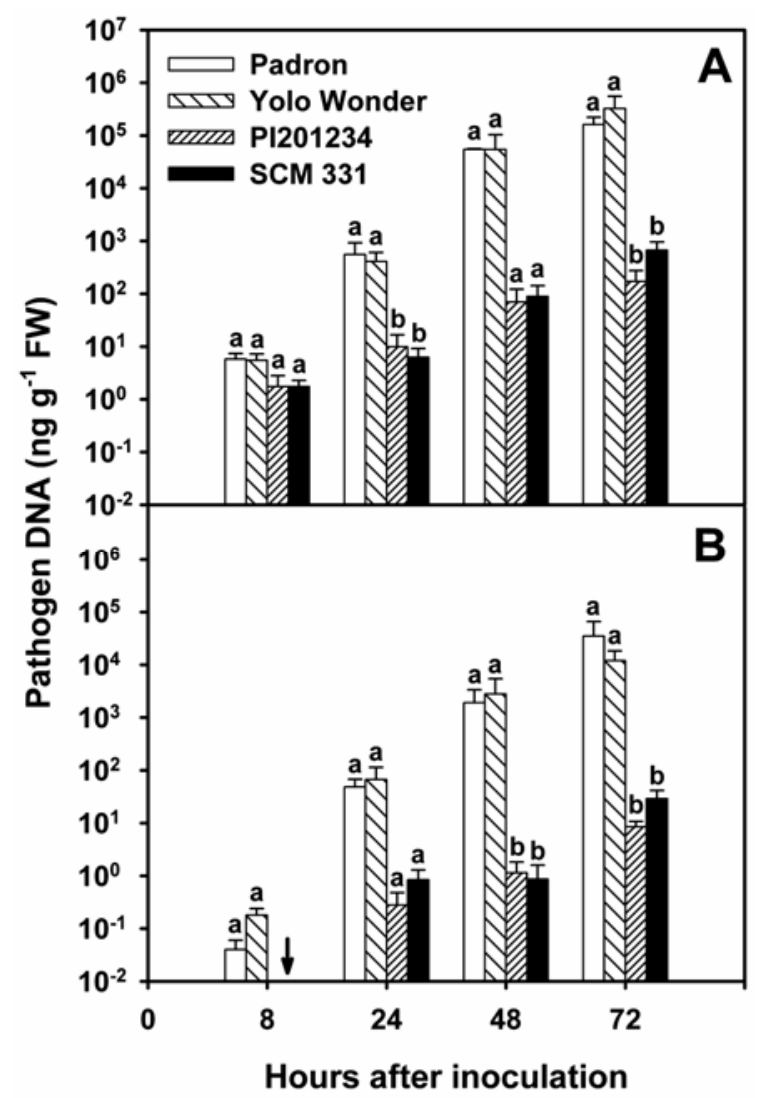

Fig. 4. Phytophthora capsici DNA quantification in stems of different pepper cultivars inoculated with A, UDC196Pc or B, UDC248Pc. Vertical arrow ( $\downarrow)$ indicates DNA samples (PI201234 and SCM 331) that could not be quantified. Data are the mean and standard error of three independent experiments. Within the same time postinoculation, different letters indicate significant differences between cultivars in a Kruskal-Wallis test $(P \leq 0.05)$ followed by the multiple comparison procedure of Conover (10). 
found in other pathogen-plant interactions (15-17) as well as in other Phytophthora spp., although using different real-time chemistries (26). The $\mathrm{Ct}$ values depend on both the amount of starting DNA and the genomic organization of the target sequences recognized by the sequence-specific primer pair; therefore, the efficiency of the technique will improve if the target DNA is present in many copies in the genome, as is the case with rDNA. This sensitivity was similar to that achieved in previous works using conventional PCR but less than that obtained with a nested PCR assay (50). These results agree with those published recently by Bonants et al. (6) working on $P$. fragariae. They obtained equivalent detection limits by using either conventional PCR or a TaqMan assay but higher sensitivity with a nested PCR. In any case, with this sensitivity, pathogen abundance can be reliably quantified from the very beginning of the infection time course and even in tissues exhibiting a low degree of infection.

In a parallel assay, the influence of plant samples on quantification was tested (data not shown). Serial dilutions (10-fold) of pathogen DNA were mixed with an equal amount of plant DNA. This mixture possibly could reflect an infection from a range of $1: 1$ (a very heavy infection) to a range of $1: 10^{6}$ (an early stage of infection). The presence of a host sample of DNA did not produce any interference in the quantification. Furthermore, with this technique, the sensitivity of the method was not affected by the presence of a plant DNA sample, as occurs with conventional and nested PCR (50).

In a real-time PCR assay, the accumulation of the amplicon can be detected using either specific detection methods such as TaqMan probes $(25,54,57)$ or nonspecific methods like SYBR Green (36). The advantage of SYBR Green is that, in contrast to fluorogenic probes, it does not require the design of specific complementary fragments to the target DNA and, therefore, the reaction cost is limited compared with real-time PCRs that depend on hybridization of labeled sequence-specific probes. The main disadvantage of this method is that it binds double-stranded DNA and, therefore, it also can associate with primer-dimers and nonspecific products, which can seriously disturb the interpretation of the results. However, this major drawback can be overcome with the use of melting curve temperature analysis at the end of the PCR assay (46). At the end of the cycling reactions, the products are melted by slowly increasing the temperature while continually monitoring the fluorescence. After melting curve analysis in our assay, the use of unspecific SYBR Green dye for quantifying the target amplicon $\left(\approx 452 \mathrm{bp}, \mathrm{Tm}=86.5^{\circ} \mathrm{C}\right)$ required a $84^{\circ} \mathrm{C}$ fluorescence emission reading step in the amplification program to eliminate any interference caused by the accumulation of unspecific PCR products. At that temperature, the nonspecific products will be denatured and only the fluorogenic emission from the target amplicon would result.

One of the results in this work is that the real-time PCR method developed here is able to quantify pathogen invasion in the absence of visible host plant symptoms. Although the first visible symptoms appeared in plants by day four after infection, quantification was possible at earlier times (as soon as $8 \mathrm{~h}$ postinoculation) in totally asymptomatic plants. Thereafter, the amount of pathogen DNA either increased sharply or varied more slightly during the study period, but in no case were the symptoms observed in inoculated plants. It must be pointed out that $P$. capsici is detected in leaves at $8 \mathrm{~h}$ postinoculation. It is surprising that the pathogen can invade and colonize the host so fast. This fact probably is due to the pathogen's ability to move through the vascular system and the small size of the plants at the time of the experiments. It was also an unexpected result that the pathogen was not isolated at $8 \mathrm{~h}$ after inoculation, taking into account that pathogen DNA was detected at that time. Maybe nonviable pathogen cells were present at that time. Another possibility is that the pathogen colonized only the outer layers of cells at that time, after which surface sterilization could have killed the pathogen.
The amount of pathogen DNA quantified $72 \mathrm{~h}$ after inoculation in each pepper genotype correlated with the level of susceptibility or resistance to disease caused by $P$. capsici (as indicated by severity of symptoms). Maximal absolute amounts of pathogen DNA were quantified in susceptible genotypes Yolo Wonder and Padrón (the most severely diseased genotypes), where measurements in stems ranged from $3.3 \times 10^{5} \mathrm{ng} \mathrm{g}^{-1} \mathrm{FW}$ in UDC196PcYolo Wonder to $1.6 \times 10^{5} \mathrm{ng} \mathrm{g}^{-1} \mathrm{FW}$ in UDC196Pc-Padron. Actual amounts of $P$. capsici DNA varied considerably for a given pepper genotype- $P$. capsici isolate interaction and, in some cases, between $P$. capsici isolates for a given pepper genotype. In the same way, smaller amounts of pathogen DNA were quantified in PI201234 and SCM331 plants, in that order. These two cultivars also produced fewer diseased plants or even none at all. Therefore, reduced disease severity in those cultivars considered resistant corresponded to the results of the quantitative analysis of pathogen DNA. In recent years, several different studies have demonstrated the utility of real-time PCR to discriminate between plant genotypes displaying different levels of resistance $(9,17,34,45,59)$. Vandemark and Barker (55), studying the $P$. medicaginis-alfalfa interaction, were able to discriminate among three alfalfa populations with different levels of resistance. They also detected less pathogen DNA in highly resistant alfalfa populations than in more susceptible ones. Moreover, the results of our work corroborate others published previously which established clear differences in resistance among SCM331 and PI201234 (resistant cultivars) and Yolo Wonder (susceptible genotype) $(4,19,20)$. The difference with the present work is that previous classifications of peppers susceptible or resistant to Phytophthora root rot were based on the evaluation of external symptoms and measurement of incidence and severity

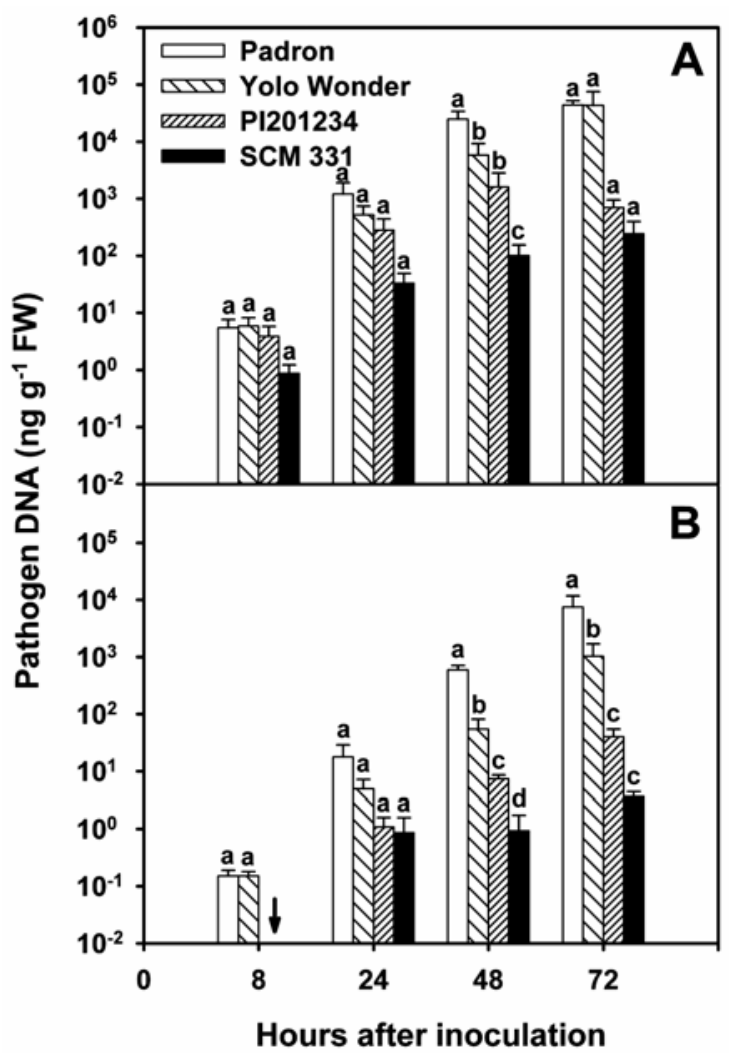

Fig. 5. Phytophthora capsici DNA quantification in roots of different pepper cultivars inoculated with A, UDC196Pc or B, UDC248Pc. Vertical arrow ( $\downarrow)$ indicates DNA samples (PI201234 and SCM 331) that could not be quantified. Data are the mean and standard error of three independent experiments. Within the same time postinoculation, different letters indicate significant differences between cultivars in a Kruskal-Wallis test $(P \leq 0.05)$ followed by the multiple comparison procedure of Conover (10). 
of plant symptoms, which is time consuming and sometimes inconclusive.

In terms of pathogen ability to infect the plant, it seemed clear that the more virulent isolate had a better capacity not only to infect the plant sooner but also to spread quicker during the time course of infection. In general, the average amount of pathogen DNA was higher for UDC196Pc-infected plants than for the UDC248Pc-infected ones. Moreover, the accumulation of pathogen DNA was rapid in susceptible genotype-most virulent isolate interactions whereas, in less compatible interactions, it was more progressive and notable increases in pathogen amount did not take place, the quantity of pathogen DNA being more constant over time. Considering all these results, the difference in virulence of the two $P$. capsici isolates could be attributed to differences in pathogen amount in infected plants, among other factors. However, a clear correlation between the virulence of a pathogen and the amount of pathogen present in the plant does not always exist. Sometimes, more virulent isolates do not involve an increase in pathogen colonization $(34,53)$.

Another interesting aspect was the different amounts of pathogen DNA in the different tissues collected. Comparatively, the amount of pathogen DNA in leaves was much lower than that quantified in roots which, in turn, was less than that occurring in stems. This tissue difference suggests either a temporal sequence of systemic colonization by the pathogen or a differential response of the plant defense mechanisms. Differences in the level of colonization of different tissues by the pathogen have been reported in other plant-pathogen interactions $(34,59)$. It has been reported that some plant defense-related genes, which encode pathogenesis-related proteins, display a differential expression in various pepper organs in response to pathogen infection $(27,28$, 49). Such responses could be responsible for that differential distribution, preventing pathogen advance, especially in the cultivars that are more resistant.

A final conclusion of the present work was that the local pepper cv. Padrón displayed an infection and quantification pattern similar to that in Yolo Wonder, suggesting that it may have a similar degree of susceptibility. Padrón is a pepper cultivar of high economic importance in Galicia (northwestern Spain) (14). The results in this study have demonstrated its level of susceptibility to Phytophthora root rot, the most important disease of pepper crops in this region (44). The real-time PCR developed here, together with disease severity studies, will enable the selection of the most resistant plants within the Padrón cultivar for disease resistance breeding in the future.

\section{ACKNOWLEDGMENTS}

This work was supported by grants from MEC (project AGF99-0301) and XUGA (project PGDIT99AGR10301). C. Silvar held a fellowship from MEC. We thank F. Rodríguez (SXAIN, Universidade da Coruña, Spain) for her technical assistance and T. Berke (former employee of AVRDC, Taiwan) for kindly supplying the PI201234 and SCM331 seed.

\section{LITERATURE CITED}

1. Alcantara, T. P., and Bosland, P. W. 1994. An inexpensive disease screening technique for foliar blight of chili pepper seedlings. HortScience 29:1182-1183.

2. Bates, J. A., Taylor, E. J. A., Kenyon, D. M., and Thomas, J. E. 2001. The application of real-time PCR to the identification, detection and quantification of Pyrenophora species in barley seed. Mol. Plant Pathol. 2:49-57.

3. Bermingham, S., Maltby, L., and Cooke, R. C. 1995. A critical assessment of the validity of ergosterol as an indicator of fungal biomass. Mycol. Res. 99:479-484.

4. Black, L. L., and Berke, T. 1998. Breeding for Phytophthora resistance in pepper. Xth Eucarpia Meeting on Genetics and Breeding of Capsicum and Eggplant. Avignon, France.

5. Böhm, J., Hahn, A., Schubert, R., Bahnweg, G., Adler, N., Nechwatal, J., Oehlmann, R., and Obwald, W. 1999. Real-time quantitative PCR: DNA determination in isolated spores of the mycorrhizal fungus Glomus mosseae and monitoring of Phytophthora infestans and Phytophthora citricola in their respective host plants. J. Phytopathol. 147:409-416.

6. Bonants, P. J. M., van Gent-Pelzer, M. P. E., Hoofman, R., Cooke, D. E. L., Guy, D. C., and Duncan, J. M. 2004. A combination of baiting and different PCR formats, including measurement of real-time quantitative fluorescence, for the detection of Phytophthora fragariae in strawberry plants. Eur. J. Plant Pathol. 110:689-702.

7. Bosland, P. W., and Lindsey, D. L. 1991. A seedling screen for Phytophthora root rot of pepper, Capsicum annuum. Plant Dis. 75:1048-1050.

8. Bowers, J. H., and Mitchell, D. J. 1991. Relationships between inoculum level of Phytophthora capsici and mortality of pepper. Phytopathology 81:178-184.

9. Brouwer, M., Lievens, B., van Hemelrijck, W., van den Ackerveken, G., Cammue, B. P. A., and Thomma, B. P. H. J. 2003. Quantification of disease progression of several microbial pathogens on Arabidopsis thaliana using real-time fluorescence PCR. FEMS Microbiol. Lett. 228:241-248.

10. Conover, W. J. 1980. Practical Nonparametric Statistics. John Wiley \& Sons, Inc., New York.

11. Cooke, D. E. L., Drenth, A., Duncan, J. M., Wagels, G., and Brasier, C. M. 2000. A molecular phylogeny of Phytophthora and related Oomycetes. Fungal Genet. Biol. 30:17-32.

12. Dan, H., Ali-Khan, A. T., and Robb, J. 2001. Use of quantitative PCR diagnostics to identify tolerance and resistance to Verticillium dahliae in potato. Plant Dis. 85:700-705.

13. Dewey, F. M., Thornton, C. R., and Gilligan, C. A. 1997. Use of monoclonal antibodies to detect, quantify, and visualize fungi in soil. Adv. Bot. Res. 24:276-308.

14. Estrada, B., Bernal, M. A., Díaz, J., Pomar, F., and Merino, F. 2000. Fruit development in Capsicum annuum: Changes in capsaicin, lignin, free phenolics and peroxidase patterns. J. Agric. Food Chem. 48:6234-6239.

15. Filion, M., St.-Arnaud, M., and Jabaji-Hare, S. H. 2003. Quantification of Fusarium solani $\mathrm{f}$. sp. phaseoli in mycorrhizal bean plants and surrounding mycorrhizosphere soil using real-time polymerase chain reaction and direct isolations on selective media. Phytopathology 93:229-235.

16. Filion, M., St-Arnaud, M., and Jabaji-Hare, S. H. 2003. Direct quantification of fungal DNA from soil substrate using real-time PCR. J. Microbiol. Methods 53:67-76.

17. Gachon, C., and Saindrenan, P. 2004. Real-time PCR monitoring of fungal development in Arabidopsis thaliana infected by Alternaria brassicicola and Botrytis cinerea. Plant Physiol. Biochem. 42:367-371.

18. Gardner, R. M., Tindall, G. W., Cline, S. M., and Brown, K. L. 1993. Ergosterol determination activated sludge and its application as a biochemical marker for monitoring fungal biomass. J. Microbiol. Methods 17:49-60.

19. Gil Ortega, R., Español, C. P., and Zueco, J. C. 1991. Genetics of resistance to Phytophthora capsici in the pepper line "SCM-334". Plant Breed. 107:50-55

20. Gil Ortega, R., Español, C. P., and Zueco, J. C. 1995. Interactions in the pepper-Phytophthora capsici system. Plant Breed. 114:74-77.

21. Gretenkort, M. A., and Ingram, D. S. 1993. The use of ergosterol as a quantitative measure of the resistance of cultured tissues of Brassica napus spp. oleifera to Leptosphaeria maculans. J. Phytopathol. 138:217-224.

22. Harrison, J. G., Barker, H., Lowe, R., and Rees, E. A. 1990. Estimation of amounts of Phytophthora infestans mycelium in leaf tissue by enzymelinked immunosorbent assay. Plant Pathol. 34:557-564.

23. Hayden, K. J., Rizzo, D., Tse, J., and Garbelotto, M. 2004. Detection and quantification of Phytophthora ramorum from California forests using a real-time polymerase chain reaction assay. Phytopathology 94:1075-1083.

24. Hoffman, T., Schmidt, J. S., Zheng, X., and Bent, A. F. 1999. Isolation of ethylene-insensitive soybean mutants that are altered in pathogen susceptibility and gene-for-gene disease resistance. Plant Physiol. 119:935-950.

25. Holland, P. M., Abramson, R. D., Watson, R., and Gelfand, D. H. 1991. Detection of specific polymerase chain reaction product by utilizing the 5'-3'exonuclease activity of Thermus aquaticus DNA polymerase. Proc. Natl. Acad. Sci. USA 88:7276-7280.

26. Ippolito, A., Schena, L., and Nigro, F., Ligorio, V. S., and Yaseen, T. 2004. Real-time detection of Phytophthora nicotianae and P. citrophthora in citrus roots and soil. Eur. J. Plant Pathol. 110:833-843.

27. Jung, H. W., and Hwang, B. K. 2000. Pepper gene encoding a basic $\beta-1,3-$ glucanase is differentially expressed in pepper tissues upon pathogen infection and ethephon or methyl jasmonate treatment. Plant Sci. 156: 23-34.

28. Jung, H. W., Kim, W., and Hwang, B. K. 2003. Three pathogen-inducible genes encoding lipid transfer protein from pepper are differentially activated by pathogens, abiotic, and environmental stresses. Plant Cell Environ. 26:915-928.

29. Karpovich-Tate, N., Spanu, P., and Dewe, F. M. 1998. Use of monoclonal antibodies to determine biomass of Cladosporium fulvum in infected tomato leaves. Mol. Plant-Microbe Interact. 11:710-716. 
30. Larkin, R. P., Ristaino, J. B., and Campbell, C. L. 1995. Detection and quantification of Phytophthora capsici in soil. Phytopathology 85:1057-1063.

31. Maniatis, T., Fritsch, E. F., and Sambrook, J. 1982. Molecular Cloning: A Laboratory Manual. Cold Spring Harbor Laboratory, Cold Spring Harbor, NY.

32. Martin, F., Delaruelle, A., and Hilberty, J. L. 1990. An improved ergosterol assay to estimate fungal biomass in ectomycorrhizas. Mycol. Res. 94:1059-1064.

33. McCartney, H. A., Foster, S. J., Fraaije, B. A., and Ward, E. 2003. Molecular diagnostics for fungal plant pathogens. Pest. Manage. Sci. 59:129-142.

34. Mercado-Blanco, J., Collado-Romero, M., Parrilla-Araujo, S., RodríguezJurado, D., and Jiménez-Díaz, R. M. 2003. Quantitative monitoring of colonization of olive genotypes by Verticillium dahliae pathotypes with real-time polymerase chain reaction. Physiol. Mol. Plant Pathol. 63:91105.

35. Miller, S. A. 1996. Detecting propagules of plant pathogenic fungi. Adv. Bot. Res. 23:73-102.

36. Morrison, T. B., Weis, J. J., and Wittwer, C. T. 1998. Quantification of low-copy transcripts by continuous SYBR Green I monitoring during amplification. BioTechniques 24:954-962.

37. Mumford, R. A., Walsh, K., Barker, I., and Boonham, N. 2000. Detection of potato mop top virus and tobacco rattle virus using a multiplex realtime fluorescent reverse-transcription polymerase chain reaction assay. Phytopathology 90:448-453.

38. Newton, A. C., and Reglinski, T. 1993. An enzyme-linked immunosorbent assay for quantifying mildew biomass. J. Plant. Dis. Prot. 100:176-179.

39. Nuez, F., Gil, R., and Costa J. 1996. El cultivo de pimientos, chiles y ajíes. Ediciones Mundi-Prensa, Madrid.

40. Pacovsky, R. S., and Bethlenfalvay, G. J. 1982. Measurement of the extraradical mycelium of a vesicular-arbuscular mycorrhizal fungus in soil by chitin determination. Plant Soil 68:143-147.

41. Palloix, A., Daubeze, A. M., and Pochard, E. 1988. Phytophthora root rot of pepper. Influence of host genotype and pathogen strain on the inoculum density-disease severity relationships. J. Phytopathol. 123:25-33.

42. Pegg, G. F., and Brady, B. L. 2002. Verticillium Wilts. CAB International, Wallingford, UK.

43. Plassard, C. S., Mousain, D. G., and Salsac, L. E. 1982. Estimation of mycelia growth of basidiomycetes by means of chin determination. Phytochemistry 21:345-348.

44. Pomar, F., Bernal, M. A., Collar, J., Díaz, J., Caramelo, C., Gayoso, C., Novo, M., Prego, C., Saavedra, A., Silvar, C., and Merino, F. 2001. A survey of "Tristeza" of pepper in Galicia and the fungal pathogens causing the disease. Capsicum Eggplant Newsl. 20:90-93.

45. Qi, M., and Yang, Y. 2002. Quantification of Magnaporthe grisea during infection of rice plants using real-time polymerase chain reaction and northern blot/phosphimaging analyses. Phytopathology 92:870-876.
46. Ririe, K. M., Rasmussen, R. P., and Wittwer, C. T. 1997. Product differentiation by analysis of DNA melting curves during the polymerase chain reaction. Anal. Biochem. 245:154-160.

47. Schaad, N. W., Frederick, R. D., Shalev, A., Shaw, J., Schneider, W. L., Hickson, R., Petrillo, M. D., and Luster, D. G. 2003. Advances in molecular-based diagnostics in meeting crop biosecurity and phytosanitary issues. Annu. Rev. Phytopathol. 41:305-324.

48. Schena, L., Nigro, F., Ippolito, A., and Gallitelli, D. 2004. Real-time quantitative PCR: A new technology to detect and study phytopathogenic and antagonistic fungi. Eur. J. Plant Pathol. 110:893-908.

49. Shin, R., Lee, G. J., Park, C. J., Kim, T. Y., You, J. S., Nam, Y. W., and Paek, K. H. 2001. Isolation of pepper mRNAs differentially expressed during the hypersensitive response to tobacco mosaic virus and characterization of a proteinase inhibitor gene. Plant Sci. 161:727-737.

50. Silvar, C., Duncan, J. M., Cooke, D. E. L., Williams, N. A., Díaz, J., and Merino, F. 2005. Development of specific PCR primers for identification and detection of Phytophthora capsici Leon. Eur. J. Plant Pathol. 112:4352 .

51. Srivastava, A. K., and Arora, D. K. 1997. Evaluation of a polyclonal antibody immunoassay for detection and quantification of Macrophomina phaseolina. Plant Pathol. 46:785-794.

52. Takenaka, S. 1995. Dynamics of fungal pathogens in host plant tissues. Can. J. Bot. 73:S1275-S1283.

53. Thomma, B. P. H. J., Tadesse, Y. S. H., Jacobs, M., and Browkaert, W. F. 1999. Disturbed correlation between fungal biomass and $\beta$-glucuronidase activity in infections of Arabidopsis thaliana with transgenic Alternaria brassicicola. Plant Sci. 148:31-36.

54. Tyagi, S., and Kramer, F. R. 1996. Molecular beacons: Probes that fluoresce upon hybridization. Nat. Biotechnol. 14:303-308.

55. Vandemark, G. J., and Barker, B. M. 2003. Quantifying Phytophthora medicaginis in susceptible and resistant alfalfa with a real-time fluorescent assay. J. Phytopathol. 151:577-583.

56. Ward, E., Tahiri-Alaouri, A., and Antoniw, J. F. 1998. Applications of PCR in fungal-plant interactions. Pages 289-307 in: Application of PCR in Mycology. P. D. Bridge, D. K. Arora, C. A. Reddy, and R. P. Elander, eds. CAB International, London.

57. Whitcombe, D., Theaker, J., Guy, S. P., Brown, T., and Little, S. 1999. Detection of PCR products using self-probing amplicons and fluorescence. Nat. Biotechnol. 17:804-807.

58. Winton, L. M., Manter, D. K., Stone, J. K., and Hansen, E. A. 2003. Comparison of biochemical, molecular, and visual methods to quantify Phaeocryptopus gaeumannii in Douglas-Fir foliage. Phytopathology 93:121-126.

59. Zhou, X. G., and Everts, K. L. 2004. Quantification of root and stem colonization of watermelon by Fusarium oxysporum f. sp. niveum and its use in evaluating resistance. Phytopathology 94:832-841. 